\section{B A Institute of \\ YK Business Administration \\ TK \\ Karachi \\ Leadership and Ideas for Tomorrow}

Business Review

Volume 9 Issue 2 July-December 2014

7-1-2014

\title{
Wealth effect of mergers \& acquisitions in emerging market: A case of Pakistan's banking sector
}

\author{
Sana Tauseef \\ Institute of Business Administration Karachi, Pakistan \\ Mohammad Nishat \\ Institute of Business Administration Karachi, Pakistan
}

Follow this and additional works at: https://ir.iba.edu.pk/businessreview

Part of the Business Analytics Commons, Business and Corporate Communications Commons, Corporate Finance Commons, and the Finance and Financial Management Commons

\section{c) (i)}

This work is licensed under a Creative Commons Attribution 4.0 International License.

\section{Recommended Citation}

Tauseef, S., \& Nishat, M. (2014). Wealth effect of mergers \& acquisitions in emerging market: A case of Pakistan's banking sector. Business Review, 9(2), 24-39. Retrieved from https://doi.org/10.54784/ 1990-6587.1269

This article is brought to you by iRepository for open access under the Creative Commons Attribution 4.0 License and is available at https://ir.iba.edu.pk/businessreview/vol9/iss2/3. For more information, please contact irepository@iba.edu.pk. 


\title{
ARTICLE
}

\section{WEALTH EFFECT OF MERGERS \& ACQUISITIONS IN EMERGING MARKET: A CASE OF PAKISTAN'S BANKING SECTOR}

\author{
Sana Tauseef, \\ Institute of Business Administration Karachi, Pakistan \\ Mohammad Nishat, \\ Institute of Business Administration Karachi, Pakistan
}

\begin{abstract}
This study investigates the short-term market response associated with the announcement of seven merger and acquisition deals in the banking sector of Pakistan during the period 2003 to 2008 using the event study methodology. The results indicate statistically significant investor reactions around the merger announcements. For individual target and bidder banks, the cumulative abnormal returns (CARs) range from significant positive to significant negative. The combined mean CAR for the bidder group is significant positive and for target group, the mean CAR is significant negative. The mean CAR for the combined banks in the domestic mergers is also positive but is largely impacted by the substantial positive CAR of one bidder bank.
\end{abstract}

Field of Research: Merger \& Acquisition, emerging market, banking

JEL: G34, G21

\section{Introduction}

In the face of technological advancement, globalization, and increased competition, the firms all over the world are trying to maintain their competitive position. There is a growing trend towards consolidation to reap the benefits through synergies, thereby, enhancing efficiency and performance. The same trend has been observed in Pakistan. After the year 1998, a large number of mergers and acquisitions (M\&A) have taken place every year in Pakistan and more than 50 percent of these M\&A have taken place in the financial sector. This paper attempts to measure the short-term wealth effect of M\&A for the target and bidder banks in Pakistan.

\section{Literature Review}

A lot of empirical research has been done to explore the wealth effect of merger activity in the developed economies, especially US, UK, and Europe. The studies conducted to analyze the wealth creation through mergers use different measures. One set of studies uses the event study methodology, looking at the short to medium run stock performance of the bidder, target and the merged entity. This methodology is based on the assumption of efficient market where the stock prices react in a timely and unbiased manner to new information (Fama, 1970; Roberts, 1967). The other set of studies looks at the accounting performance indicators, like return on equity and various cash flow measures, to compare the pre- and post-merger performance. Such studies believe that the gains or losses resulting 
from a merger eventually appear in the firm's accounting records (Tuch and Sullivan, 2007). Both sets of studies have ended in variable results.

Short-run event studies including the US takeovers during 1960s (Asquith,1983) and UK takeovers during 1950s (Franks and Harris, 1989) reported significant positive returns to the acquirers. However, the remaining event studies, both short run and long run, conducted on US and UK takeovers provide either no significant change or report significant negative returns for the acquirers (Tuch and Sullivan, 2007).On the other hand, the target firms' announcement returns in US and Europe are found to be large and significantly positive (Kiymaz and Baker, 2008). According to these researches, the mergers merely transfer the wealth from the acquiring firms to the target shareholders and no wealth is created in process. A study covering 54 mergers including 13 European banking markets of European Union and the Swiss market for the period 1988 to 1997 has reported positive and significant increase in the shareholder wealth of bidder and target banks (Cybo-Ottone and Murgia, 2000). Campa and Hernando (2004) found a negative return around the bid announcement for the regulated European Union acquirers and reported no significant return for the bidders from unregulated industries. In Canada, the acquiring firms are reported to have positive returns (Ben-Amar and Andre, 2006).

The evidence from the research using accounting information is also mixed. Moreover, the researches using the accounting information are difficult to compare since they use different measures to capture the change in performance. The studies examining the postbid accounting performance of the acquirers for the period between 1948-1977 in UK reported either a decline in the profitability following the merger (Meeks, 1977; Ravenscroft and Scherer, 1987) or significantly lower returns for the acquirers compared to the nonacquirers (Dickerson, 1997). The study by Healy (1992) reports an improvement in the asset productivity, measured through operating Cash flow return on market value of assets, of the acquiring firms in US. Andrade (2001) also finds an improvement in the post-merger performance, measured through ratio of cash flow to sales, for the US mergers. The study conducted by Altunbas and Marques (2004) on mergers taking place during the period 19922001 in Europe reported superior post-merger performance; however, the performance improvement following the cross-border mergers is reported to be more compared to the performance improvement of banks entering into domestic mergers.

The mixed evidence on the returns from mergers encouraged the researchers to examine the different bid characteristics to identify the drivers of differential performance. These studies report that for strategically closer institutions the performance improves more than for dissimilar institutions, thereby supporting the synergy hypotheses (Altunbas and Marques, 2004; Tuch and Sullivan, 2007). Moreover, in both the domestic and cross-border mergers the institutions performing very well prior to mergers are not able to improve their performance as much as the firms which are low performers before merger transactions. The studies also report that the hostile takeovers, where the takeover activity takes place despite of the target management's opposition, are associated with better performance if excessive takeover premiums are not paid. This can be taken as an indication that the hostile takeovers play a governance role and they target the firms where managers are under performing (Tuch and Sullivan, 2007).

Although there is extensive evidence available for developed countries on the issue, little research exists for the emerging and less developed economies. In a study of crossborder mergers and acquisitions by the Chinese firms positive and significant wealth gains 
were found for the acquiring firms (Boateng, Qian and Tianle, 2008). Mishra and Goel (2005) in their study of a merger deal in Indian energy and petrochemical sector found that despite the deal appearing favorable to the shareholders of bidder company, the announcement returns for bidder were found to be negative. However, the returns for the target firm were positive. The combined firm was reported to have negative excess returns which were linked to the managerialism hypothesis, indicating that the acquirer's management is motivated by its own self-interest and is not pursuing the merger deal for their shareholders' benefit. In the Indian banking Industry, merger announcements were found to have a positive and significant wealth effect both for the bidder and the target banks (Anand and Singh, 2008). In Pakistan, a large number of mergers and acquisitions have taken place after the year 1998 and more than 50 percent of these transactions took place in the financial sector, including banks, leasing companies, modarabas, and mutual funds. This resulted mainly due to the State Bank of Pakistan's regulatory policies, which focused on consolidating the weak financial institutions by strengthening their capital base. The trend towards consolidation in financial sector is still continuing and therefore there is a need to study the wealth creation for the shareholders of targets and bidders in this sector. Building on the earlier studies done on the topic in developed and other less developed countries, we attempt to examine the wealth impact of bank merger deals in Pakistan.

\section{Data and Research Design}

Our research uses the standard event study methodology to measure the impact of merger announcements on the wealth of the merging firms' shareholders. To conduct the study, we consider the following seven mergers/acquisitions that took place in the banking sector of Pakistan during the period 2003 to 2008. Exhibit 1 illustrates the sample mergers with the respective announcement dates and the effective merger dates. We classify the sample mergers into three broad categories:

I. Acquisitions of Pakistani banks by the foreign investors include the acquisition of Saudi Pak Bank (renamed as Silkbank) by a Consortium comprising of IFC, Bank Muscat, Nomura International and Sinthos Capital and the acquisition of Crescent Bank by SAMBA Financial group.

II. Mergers of Pakistani banks with the other domestic banks includethe merger of NIB and PICIC, the amalgamation of Trust Investment Bank Limited (TIBL) and Fidelity Investment Bank Limited (FIBL) together with the Doha Bank Pakistan Branches which created Trust Commercial Bank Limited and the acquisition of Platinum Commercial Bank Limited by KASB.

III. Mergers of Pakistani banks with the foreign banks operating in Pakistan include the acquisition of Union Bank by the Standard Chartered Bank and the amalgamation of Prime Bank with ABN Amro.

The study tests the following hypothesis:

"The merger announcements in the banking sector of Pakistan do not create shareholders' wealth for the merging banks"

In order to test the hypothesis, the study requires the announcement dates for each of the seven mergers, the window period and the clean period data for each merger deal. Announcement date $(t=0)$ is the date on which the information about the merger deal was 
first made public. These dates are obtained from the news clipping available on the websites of Daily Business Recorder (www.brecorder.com.pk) and Daily Dawn (www.dawn.com.pk).

The event window has been taken from $t=-30$ to $t=+30$, where $t=-30$ represents 30 days before the merger announcement date $(\mathrm{t}=0)$ and $\mathrm{t}=+30$ represents 30 days after the merger announcement is made. We employ the single-factor market model to compute the abnormal return for each bank stock in the 61-day window. The market model parameters are computed using an estimation period of 180 days before the window period for each participating firm. The period of 30 days prior to the announcement date is not included in this clean period to prevent the event's influence on the parameter estimates.

Exhibit 1: Announcement dates and the bidder and target banks of sample merger deals

\begin{tabular}{|c|l|l|l|l|}
\hline $\begin{array}{c}\text { Serial } \\
\text { Number }\end{array}$ & \multicolumn{1}{|c|}{ Bidder Bank } & \multicolumn{1}{|c|}{ Target Bank/s } & $\begin{array}{c}\text { Announcement } \\
\text { Date }\end{array}$ & $\begin{array}{c}\text { Merger/ } \\
\text { Acquisition Date }\end{array}$ \\
\hline 1 & $\begin{array}{l}\text { Consortium including } \\
\text { Bank Muscat and } \\
\text { Japan's Nomura }\end{array}$ & Saudi Pak Bank & January 07, 2008 & March 31, 2008 \\
\hline 2 & Samba Financial Group & Crescent Commercial Bank & Nov 17, 2006 & March 31, 2007 \\
\hline 3 & NIB & PICIC Commercial Bank & June 29, 2007 & Dec 31, 2007 \\
\hline 4 & $\begin{array}{l}\text { Trust Commercial Bank } \\
\text { (new entity) }\end{array}$ & $\begin{array}{l}\text { Trust Inv.Bank Ltd, } \\
\text { Fidelity Inv.Bank Ltd., and } \\
\text { Doha Bank }\end{array}$ & August 06, 2003 & May 05, 2004 \\
\hline 5 & $\begin{array}{l}\text { KASB } \\
\text { Standard Chartered } \\
\text { Bank (Pakistan), }\end{array}$ & Union Bank Limited & August 09, 2006 & Dec 30, 2006 \\
\hline 7 & $\begin{array}{l}\text { ABN Amro (Pakistan) } \\
\text { Limited }\end{array}$ & Prime Commercial Bank & Mar 05, 2007 & Sept 01, 2007 \\
\hline
\end{tabular}

The following market model is employed for the parameter estimations:

$$
\mathbf{A} \mathbf{R}_{i t}=\mathbf{R}_{i t}-\mathbf{E}\left(\mathbf{R}_{i t}\right)
$$

where, $\mathrm{AR}_{i t}=$ Abnormal return for bank stock $i$ on day $t$.

$\mathrm{R}_{i t}=$ Actual return of bank stock $i$ at time $t$.

$\mathrm{E}\left(\mathrm{R}_{i t}\right)=$ Expected return on bank stock $\mathrm{i}$ at time t.This is measured by the following equation: $\mathbf{E}\left(\mathbf{R}_{i t}\right)=\boldsymbol{\alpha}+\boldsymbol{\beta} \mathbf{R}_{m t}$

$\alpha=$ Ordinary least squares estimate of the intercept of the market model regression.

$\beta=$ Ordinary least squares estimate of the coefficient in the market model regression.

Cumulative abnormal returns are used to explore whether the share holders of the each bidder and target bank gained or lost from the respective merger deal. These CARsare computed for the period surrounding the merger announcement $(-30$ to +30$)$, i.e., from 30 days before the merger announcement to 30 days after the merger announcement, using the following equation:

$$
\mathbf{C A R}=\sum_{t=-30}^{t=+30}
$$


To examine the wealth effect for the shareholders of the bidder banks group and target banks group, the daily average abnormal returns in a 60-day window is computed for the bidder block and the target block by using the following equation for arithmetic average:

\section{$\operatorname{AVG} \mathbf{A R}_{t}=\sum \mathbf{A R}_{i t} / \mathbf{n}$}

Where, $\quad \mathrm{n}=$ Number of banks in the bidder and target groups.

The cumulative average abnormal returns for the days surrounding the merger announcement $(-30$ to +30$)$ is estimated for each group (bidder and target). The cumulative average abnormal returns for the event window is also computed for the target group in each category. Abnormal returns of the combined banks (for category $2^{1}$ )are calculated to assess the market expectations and reactions to the merger deals. The market values (i.e. market capitalization) of the bidder and target banks for the day before the merger announcement $(\mathrm{t}=-1)$ are used to compute the market value weights. ${ }^{2}$ The weighted average cumulative abnormal returns are then estimated for each merger announcement.

The average AR (abnormal return) for each target and bidder bank, the average CAR (cumulative abnormal return) for each target and bidder, the average CAR for the target banks group and bidder group, the average CAR for the targets in each of the three M\&A categories, and the CARs of combined entities are then tested for statistical significance using t-statistic.

\section{Exhibit 2: Equity market value for bidder and target banks}

\begin{tabular}{|l|l|l|l|l|l|l|l|}
\hline S. & Bidder Bank & \multicolumn{1}{|c|}{ Target Bank/s } & \multicolumn{2}{|c|}{ Market Capitalisation } & \multicolumn{2}{c|}{ Market Value Weights } \\
\cline { 4 - 8 } No. & & & Date (value as on) & Bidder Bank & Target Bank & & \\
\hline 1 & NIB & $\begin{array}{l}\text { PICIC Commercial } \\
\text { Bank }\end{array}$ & June 28, 2007 & $7,126,426,640$ & $12,088,147,500$ & $37.089 \%$ & $62.911 \%$ \\
\hline 2 & $\begin{array}{l}\text { Trust } \\
\text { Commercial } \\
\text { Bank (new } \\
\text { entity) }\end{array}$ & $\begin{array}{l}\text { Fidelity Inv.Bank } \\
\text { Ltd., and Doha Bank }\end{array}$ & August 05, 2003 & $422,476,200$ & $357,075,000$ & $54.195 \%$ & $45.805 \%$ \\
\hline 3 & KASB & $\begin{array}{l}\text { Platinum } \\
\text { Commercial Bank }\end{array}$ & February 24, 2003 & $575,446,500$ & $492,800,000$ & $53.868 \%$ & $46.132 \%$ \\
\hline
\end{tabular}

\section{Empirical Results}

Exhibit $3 \mathrm{~A}$ provides the details of the regression results for all target and bidder banks. These coefficients were used to estimate the expected returns for the respective bank during the event window.Exhibit3B gives the mean residual return for each bank and the tstatistic. From the target group, Saudi Pak Bank and Prime Commercial Bank reported significant negative mean AR. For each of the other target banks, the mean AR is statistically insignificant. Exhibit 3C summarizes the mean CAR over the 61-day event window for each bank. From the target group, six banks out of seven are found to have significant and substantial positive or negative CAR. Saudi Pak Bank, Fidelity Investment, Union Bank and Prime Commercial Bank have shown significant negative mean CAR. Crescent Commercial and PICIC have earned significant positive mean CAR. In the bidder banks group, NIB has earned a substantial and statistically significant positive mean CAR, where as the other two banks, Trust Investment and KASB have earned significant negative mean CARs.

\footnotetext{
${ }^{1}$ The required data is not available for the other two categories.

${ }^{2}$ Exhibit 2 illustrates the market value of equity as on the previous day of the merger announcement $(\mathrm{t}=-1)$
} 


\section{Target and Bidder Groups:}

Exhibit 4 presents the daily abnormal return and daily cumulative abnormal return for the target and bidder groups. Over the event window, the target group accumulated a CAR of $-2.23 \%$. A mixed trend in CAR can be observed from exhibit 4 for the target group during the 61 day event window. The CAR improved during the period of 20 days before the merger announcement by $4.65 \%$. The CAR increased by $5.91 \%$ for the period $(-1$ to +1$)$, i.e., from one day prior to announcement to one day after the merger announcement.CAR declined by $11.45 \%$ during the period $(+2$ to +30$)$, i.e., from 2 days after the merger announcement to 30 days after the merger announcement. The mean CAR for the group is negative and significant. Exhibit5 shows the announcement effects of bidder and target groups into various sub-periods within the event window. The period from 10 days prior to merger announcement till the date of merger announcement captures the highest increases in the share prices of target banks, following which the share prices have observed a sudden drop.

For the bidder group, the CAR is positive (21.07\%) and statistically significant. This combined CAR is propped up due to a substantial positive CAR earned by PICIC. In relative terms, the CAR increased by $25.88 \%$ during the 24 days prior to the merger announcement (24 to -1$)$ and then declined by $4.6 \%$ during the 30 days following the merger announcement $(+1$ to +30$)$. On the day of announcement $(t=0)$, the bidder group earned a positive return of $0.63 \%$.

\section{Exhibit 3A}

Summary Statistics-Bidder and Target Banks

\begin{tabular}{|l|c|c|}
\hline & A & $\boldsymbol{\beta}$ \\
\hline Target Banks & & 0.688 \\
\hline Saudi Pak Bank & 0.295 & 0.993 \\
\hline Crescent Commercial Bank & -0.147 & 1.160 \\
\hline PICIC & -0.017 & -0.141 \\
\hline Fidelity Investment Bank & 0.480 & 0.999 \\
\hline Platinum Commercial Bank & 0.102 & 0.808 \\
\hline Union Bank & 0.357 & 0.645 \\
\hline Prime Commercial Bank & 0.484 & 0.844 \\
\hline Bidder Banks & & 0.018 \\
\hline NIB & 0.044 & 0.240 \\
\hline Trust Investment Bank & 0.591 & \\
\hline KASB & 0.139 & \\
\hline
\end{tabular}


https://ir.iba.edu.pk/businessreview/vol9/iss2/3

DOI: https://doi.org/10.54784/1990-6587.1269

Business Review - Volume 9 Number 2

July - December 2014

Exhibit 3B

Abnormal Returns-Bidder and Target Banks

\begin{tabular}{|l|c|c|c|}
\hline & Mean AR & Standard Error & t-statistic \\
\hline Target Banks & & & \\
\hline Saudi Pak Bank & -0.387 & 0.188 & $-2.061^{*}$ \\
\hline Crescent Commercial Bank & 0.617 & 0.396 & 1.559 \\
\hline PICIC & 0.298 & 0.262 & 1.136 \\
\hline Fidelity Investment Bank & -0.514 & 0.543 & -0.947 \\
\hline Platinum Commercial Bank & -0.082 & 0.442 & -0.187 \\
\hline Union Bank & 0.199 & 0.249 & 0.800 \\
\hline Prime Commercial Bank & -0.534 & 0.175 & $-3.051^{*}$ \\
\hline Bidder Banks & & & $3.838^{*}$ \\
\hline NIB & 1.596 & 0.416 & -0.899 \\
\hline Trust Investment Bank & -0.452 & 0.503 & -0.303 \\
\hline KASB & -0.107 & 0.354 & \\
\hline
\end{tabular}

* significant at $5 \%$ level.

Exhibit 3C

Cumulative Abnormal Returns-Bidder and Target Banks

\begin{tabular}{|l|c|c|c|}
\hline & Mean CAR & Standard Error & t-statistic \\
\hline Target Banks & & & \\
\hline Saudi Pak Bank & -14.075 & 0.537 & $-26.230^{*}$ \\
\hline Crescent Commercial Bank & 31.860 & 1.355 & $23.513^{*}$ \\
\hline PICIC & 12.501 & 1.041 & $12.009^{*}$ \\
\hline Fidelity Investment Bank & -5.650 & 1.533 & $-3.686^{*}$ \\
\hline Platinum Commercial Bank & 0.129 & 0.829 & 0.155 \\
\hline Union Bank & -2.007 & 0.675 & $-2.973^{*}$ \\
\hline Prime Commercial Bank & -15.736 & 1.087 & $-14.483^{*}$ \\
\hline Bidder Banks & & & $17.851^{*}$ \\
\hline NIB & 65.582 & 3.674 & $-2.116^{*}$ \\
\hline Trust Investment Bank & -2.460 & 1.163 & $-10.109^{*}$ \\
\hline KASB & -8.122 & 0.803 & \\
\hline
\end{tabular}

*significant at 5\% level. 
https://ir.iba.edu.pk/businessreview/vol9/iss2/3

DOI: https://doi.org/10.54784/1990-6587.1269

Business Review - Volume 9 Number 2

July - December 2014

Exhibit 4: Daily and Cumulative Average Excess Returns for Target and Bidder Groups

\begin{tabular}{|c|c|c|c|c|}
\hline \multirow{2}{*}{ Event Day } & \multicolumn{2}{|c|}{ Average Excess Returns } & \multicolumn{2}{|c|}{ Cumulative Average Excess Returns } \\
\hline & Target Group & Bidder Group & Target Group & Bidder Group \\
\hline 30 & 0.330 & 1.483 & -2.226 & 21.074 \\
\hline 29 & 0.781 & 1.580 & -2.557 & 19.591 \\
\hline 28 & 0.928 & -1.489 & -3.338 & 18.011 \\
\hline 27 & -1.144 & -1.250 & -4.266 & 19.500 \\
\hline 26 & -0.125 & 0.056 & -3.122 & 20.750 \\
\hline 25 & 0.390 & -0.374 & -2.997 & 20.694 \\
\hline 24 & -1.389 & 0.726 & -3.387 & 21.068 \\
\hline 23 & -1.572 & 4.695 & -1.999 & 20.342 \\
\hline 22 & 1.997 & -0.110 & -0.427 & 15.647 \\
\hline 21 & -0.987 & -1.055 & -2.424 & 15.757 \\
\hline 20 & -2.627 & -1.626 & -1.436 & 16.812 \\
\hline 19 & -0.191 & -0.359 & 1.190 & 18.438 \\
\hline 18 & 0.111 & 0.638 & 1.381 & 18.796 \\
\hline 17 & 0.218 & -0.579 & 1.269 & 18.158 \\
\hline 16 & -0.915 & 1.210 & 1.052 & 18.737 \\
\hline 15 & -1.417 & -2.726 & 1.966 & 17.527 \\
\hline 14 & -0.503 & -0.183 & 3.384 & 20.253 \\
\hline 13 & 0.069 & -3.705 & 3.886 & 20.436 \\
\hline 12 & -1.873 & 0.030 & 3.817 & 24.141 \\
\hline 11 & -0.344 & -0.110 & 5.690 & 24.111 \\
\hline 10 & -0.182 & -0.998 & 6.034 & 24.221 \\
\hline 9 & -0.387 & 0.660 & 6.215 & 25.219 \\
\hline 8 & 0.375 & 1.528 & 6.603 & 24.558 \\
\hline 7 & 0.289 & 0.818 & 6.228 & 23.030 \\
\hline 6 & -1.431 & -2.941 & 5.938 & 22.212 \\
\hline 5 & -0.429 & 0.250 & 7.369 & 25.154 \\
\hline 4 & -1.036 & -2.427 & 7.798 & 24.904 \\
\hline 3 & -0.133 & -2.036 & 8.835 & 27.331 \\
\hline 2 & -0.252 & -0.948 & 8.968 & 29.367 \\
\hline 1 & 2.374 & 4.645 & 9.220 & 30.315 \\
\hline 0 & 2.345 & 0.630 & 6.846 & 25.670 \\
\hline-1 & 1.193 & -0.941 & 4.501 & 25.040 \\
\hline
\end{tabular}




\begin{tabular}{|c|c|c|c|c|}
\hline-2 & -1.345 & -0.688 & 3.308 & 25.982 \\
\hline-3 & 0.451 & 3.494 & 4.653 & 26.670 \\
\hline-4 & 2.272 & -3.615 & 4.202 & 23.176 \\
\hline-5 & -0.125 & -0.723 & 1.931 & 26.791 \\
\hline-6 & 0.676 & -0.504 & 2.055 & 27.514 \\
\hline-7 & -0.839 & 1.474 & 1.379 & 28.018 \\
\hline-8 & -0.323 & 1.869 & 2.218 & 26.545 \\
\hline-9 & 0.083 & 0.631 & 2.542 & 24.676 \\
\hline-10 & 0.749 & 0.931 & 2.458 & 24.044 \\
\hline-11 & -0.677 & -1.870 & 1.709 & 23.114 \\
\hline-12 & 2.070 & 2.978 & 2.386 & 24.984 \\
\hline-13 & 0.532 & 3.363 & 0.315 & 22.006 \\
\hline-14 & -0.427 & 2.877 & -0.217 & 18.644 \\
\hline-15 & 1.777 & 3.293 & 0.210 & 15.766 \\
\hline-16 & -2.304 & -1.514 & -1.567 & 12.474 \\
\hline-17 & -0.165 & 0.174 & 0.737 & 13.987 \\
\hline-18 & 2.780 & 1.447 & 0.902 & 13.813 \\
\hline-19 & -2.084 & 0.962 & -1.878 & 12.366 \\
\hline-20 & 0.359 & 1.140 & 0.206 & 11.405 \\
\hline-21 & 0.806 & 1.210 & -0.152 & 10.264 \\
\hline-22 & -0.280 & 2.362 & -0.958 & 9.054 \\
\hline-23 & 0.329 & 4.415 & -0.678 & 6.692 \\
\hline-24 & -0.005 & 3.125 & -1.007 & 2.277 \\
\hline-25 & -1.282 & 1.238 & -1.002 & -0.847 \\
\hline-26 & 1.159 & 2.691 & 0.281 & -2.085 \\
\hline-27 & 0.005 & -1.783 & -0.878 & -4.776 \\
\hline-28 & -0.578 & -2.843 & -0.883 & -2.994 \\
\hline-29 & 0.514 & -2.216 & -0.305 & -0.150 \\
\hline-30 & -0.819 & 2.065 & -0.819 & 2.065 \\
\hline Mean & -0.036 & 0.345 & 1.658 & 18.333 \\
\hline
\end{tabular}

Exhibit 5 shows that the increase in CAR during the 20 days through 11 days prior to the announcement accounted for the highest proportion of the total increase in the event window. The positive trend in CAR continued till the announcement date. During the 20 days following the merger announcement $(+1$ to +20$)$ the CAR declined which was followed by an increase in the CAR for the last 10 days in the event window ( +21 to 30) and this increase accounted for $20.22 \%$ of the total increase. 
The mean CARs for both the target and bidder groups, thus, are positive and significant at 5\%. Anand and Singh (2008) found the same trend in their study for the bidders and targets of the Indian private sector banks.

Exhibit5: Announcement Effect of merger deals on target and bidder groups' returns

\begin{tabular}{|c|c|c|c|c|c|c|c|c|c|c|}
\hline \multicolumn{11}{|c|}{ CAR-Announcement Effect for Target and Bidder groups } \\
\hline Sub-period & $\begin{array}{l}-30 \\
\text { to } \\
-21\end{array}$ & $\begin{array}{c}-20 \\
\text { to } \\
-11\end{array}$ & $\begin{array}{l}-10 \\
\text { to } \\
-1\end{array}$ & 0 & $\begin{array}{l}+1 \\
\text { to } \\
+10\end{array}$ & $\begin{array}{c}+11 \\
\text { to } \\
+20\end{array}$ & $\begin{array}{c}+21 \\
\text { to } \\
+30\end{array}$ & $\begin{array}{c}-30 \\
\text { to } \\
0\end{array}$ & $\begin{array}{c}0 \\
\text { to } \\
+30\end{array}$ & $\begin{array}{l}-30 \\
\text { to } \\
+30\end{array}$ \\
\hline \multicolumn{11}{|l|}{ Target Group } \\
\hline CAR & $\begin{array}{l}- \\
0.1 \\
5\end{array}$ & 1.86 & 2.79 & 2.35 & -0.81 & -7.47 & -0.79 & 6.85 & -9.07 & $\overline{2 .}$ \\
\hline $\begin{array}{l}\text { Announcement } \\
\text { Effect } \\
(-30 \text { to } 0)\end{array}$ & $\begin{array}{l}- \\
2.2 \\
2 \%\end{array}$ & $\begin{array}{l}27.19 \\
\%\end{array}$ & $\begin{array}{l}40.7 \\
8 \%\end{array}$ & $\begin{array}{l}34.2 \\
6 \%\end{array}$ & & & & & & \\
\hline $\begin{array}{l}\text { Announcement } \\
\text { Effect } \\
(0 \text { to }+30)\end{array}$ & & & & & $-\overline{8.95 \%}$ & $\begin{array}{l}- \\
82.34 \\
\%\end{array}$ & $-8.71 \%$ & & & \\
\hline $\begin{array}{l}\text { Announcement } \\
\text { Effect } \\
(-30 \text { to }+30)\end{array}$ & $\begin{array}{l}- \\
10 . \\
35 \\
\%\end{array}$ & $\begin{array}{l}46.93 \\
\%\end{array}$ & $\begin{array}{l}73.3 \\
9 \%\end{array}$ & $\begin{array}{l}66.1 \\
0 \%\end{array}$ & $\begin{array}{l}- \\
29.10 \\
\%\end{array}$ & $\begin{array}{l}- \\
218.4 \\
6 \%\end{array}$ & $-28.5 \%$ & & & \\
\hline \multicolumn{11}{|l|}{ Bidder Group } \\
\hline CAR & $\begin{array}{l}10 . \\
26\end{array}$ & 12.85 & 1.93 & 0.63 & -1.45 & -7.41 & 4.26 & 25.67 & -4.60 & $\begin{array}{l}21.0 \\
7\end{array}$ \\
\hline $\begin{array}{l}\text { Announcement } \\
\text { Effect } \\
(-30 \text { to } 0)\end{array}$ & $\begin{array}{l}39 . \\
98 \\
\%\end{array}$ & $\begin{array}{l}50.05 \\
\%\end{array}$ & $\begin{array}{l}7.51 \\
\%\end{array}$ & $\begin{array}{l}2.45 \\
\%\end{array}$ & & & & & & \\
\hline Announcement & & & & & $\begin{array}{c}- \\
31.52\end{array}$ & $\overline{161.1}$ & $92.71 \%$ & & & \\
\hline
\end{tabular}




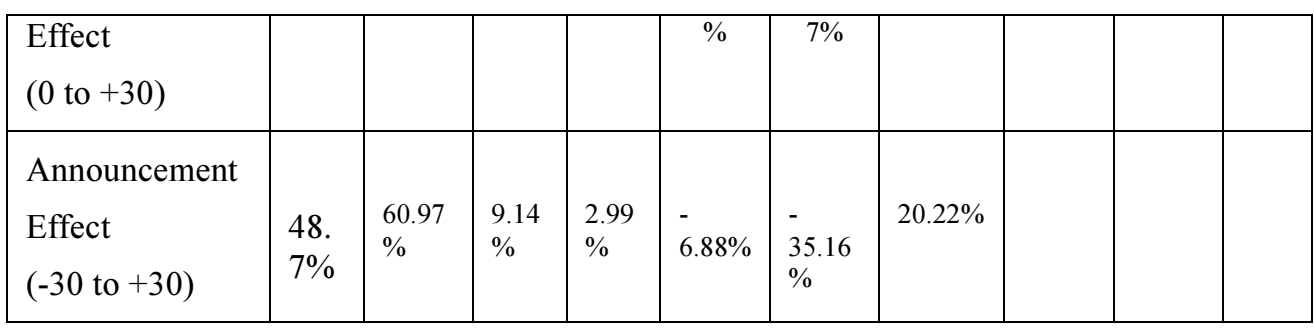

\subsection{Targets in different categories:}

Exhibit 6gives the graph of the CARs for the three target bank categories and for the total target group. The table showing the ARs and the CARs for these three target bank categories is attached in the appendix. The CARs for the targets of foreign acquirers (category 1) are positive over the entire event window except for the $30^{\text {th }}$ day prior to the merger announcement. The announcement effects for various sub-periods of the event window are given in exhibit 5B. For the targets of foreign acquiring banks, the group CAR increased during the period of 30 days prior to the merger announcement till the announcement day $(-30$ to 0$)$, and for the period between the $1^{\text {st }}$ day of announcement till 30 days $(+1$ to +30$)$, it decreased. On the announcement day, the shareholders of these targets earned an abnormal return of $4.91 \%$. The total CAR accumulated over the event window for the targets in foreign acquisitions is $7.01 \%$.

\section{Exhibit 6A: CARs for category-wise target groups and combined target group}

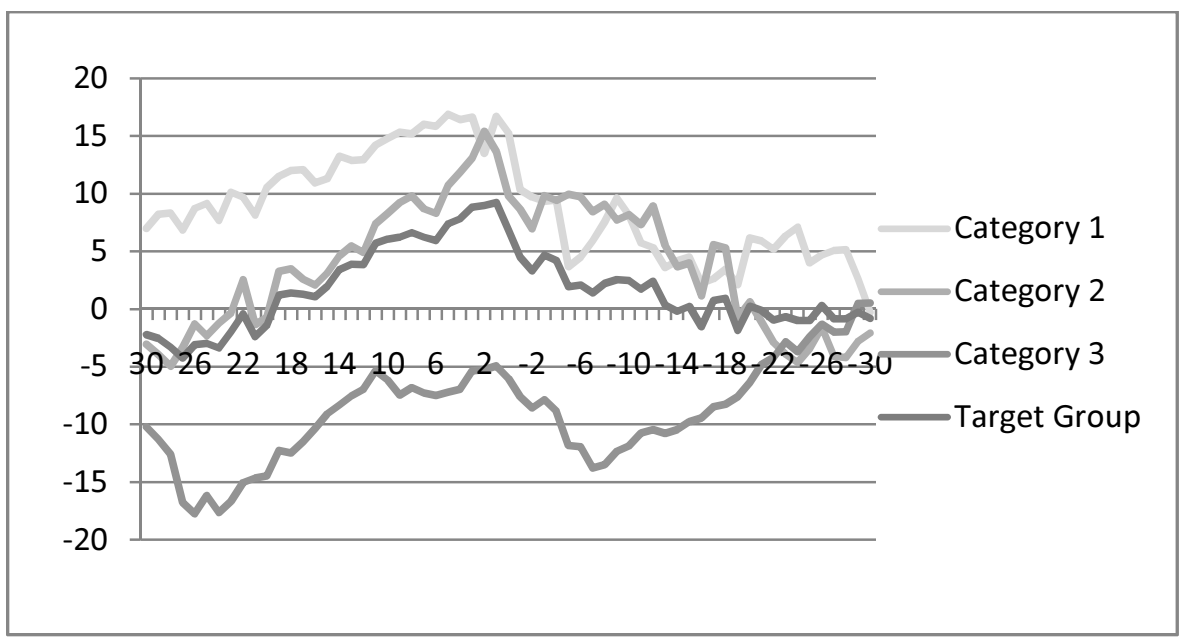


Exhibit 6B: Announcement effects of merger deals on returns of category-wise target banks

\begin{tabular}{|c|c|c|c|c|c|c|c|c|c|c|}
\hline \multicolumn{11}{|c|}{ CAR-Announcement Effect for Category-wise Targets } \\
\hline Sub-period & $\begin{array}{l}-30 \\
\text { to } \\
-21\end{array}$ & $\begin{array}{l}-20 \\
\text { to } \\
-11\end{array}$ & $\begin{array}{l}-10 \\
\text { to } \\
-1\end{array}$ & 0 & $\begin{array}{c}+1 \\
\text { to } \\
+10\end{array}$ & $\begin{array}{c}+11 \\
\text { to } \\
+20\end{array}$ & $\begin{array}{c}+21 \\
\text { to } \\
+30\end{array}$ & $\begin{array}{c}-30 \\
\text { to } \\
0\end{array}$ & $\begin{array}{c}0 \\
\text { to } \\
+30\end{array}$ & $\begin{array}{c}-30 \\
\text { to } \\
+30\end{array}$ \\
\hline \multicolumn{11}{|c|}{ Targets in Category 1} \\
\hline CAR & 5.92 & -0.20 & 4.62 & $\begin{array}{c}4.9 \\
1\end{array}$ & -0.46 & -4.27 & -3.52 & $\begin{array}{l}15 . \\
25\end{array}$ & -8.24 & 7.01 \\
\hline $\begin{array}{c}\text { Announcement } \\
\text { Effect } \\
(-30 \text { to } 0)\end{array}$ & $\begin{array}{c}38.7 \\
8 \%\end{array}$ & $\begin{array}{c}- \\
1.28 \%\end{array}$ & $\begin{array}{c}30.29 \\
\%\end{array}$ & $\begin{array}{l}32 . \\
21 \\
\%\end{array}$ & & & & & & \\
\hline $\begin{array}{c}\text { Announcement } \\
\text { Effect } \\
(0 \text { to }+30)\end{array}$ & & & & & $\begin{array}{l}- \\
13.71 \\
\%\end{array}$ & $\begin{array}{c}- \\
128.11 \\
\%\end{array}$ & $\begin{array}{c}- \\
105.67 \%\end{array}$ & & & \\
\hline \multicolumn{11}{|c|}{ Targets in Category 2} \\
\hline CAR & 1.07 & 8.41 & 1.33 & $\begin{array}{c}1.0 \\
9\end{array}$ & -1.49 & -9.03 & -2.35 & $\begin{array}{c}9.7 \\
6\end{array}$ & -12.87 & -3.06 \\
\hline $\begin{array}{c}\text { Announcement } \\
\text { Effect } \\
(-30 \text { to } 0)\end{array}$ & $\begin{array}{c}- \\
10.9 \\
8 \%\end{array}$ & $\begin{array}{c}86.20 \\
\%\end{array}$ & $\begin{array}{c}13.67 \\
\%\end{array}$ & $\begin{array}{l}11 . \\
12 \\
\%\end{array}$ & & & & & & \\
\hline $\begin{array}{c}\text { Announcement } \\
\text { Effect } \\
(0 \text { to }+30)\end{array}$ & & & & & $\begin{array}{l}- \\
11.59 \\
\%\end{array}$ & $\overline{-}$ & $-18.23 \%$ & & & \\
\hline \multicolumn{11}{|c|}{ Targets in Category 3} \\
\hline CAR & $\begin{array}{c}- \\
4.84\end{array}$ & -5.91 & 3.15 & $\begin{array}{c}1.5 \\
9\end{array}$ & -0.15 & -8.33 & 4.27 & $\begin{array}{c}- \\
6.0 \\
1\end{array}$ & -4.20 & -10.22 \\
\hline $\begin{array}{c}\text { Announcement } \\
\text { Effect } \\
(-30 \text { to } 0)\end{array}$ & $\begin{array}{l}- \\
80.5 \\
3 \%\end{array}$ & $\begin{array}{l}- \\
98.35 \\
\%\end{array}$ & $\begin{array}{c}52.38 \\
\%\end{array}$ & $\begin{array}{l}26 . \\
51 \\
\%\end{array}$ & & & & & & \\
\hline $\begin{array}{c}\text { Announcement } \\
\text { Effect } \\
(0 \text { to }+30)\end{array}$ & & & & & $\begin{array}{c}- \\
3.52 \%\end{array}$ & $\begin{array}{c}- \\
198.12 \\
\%\end{array}$ & $101.64 \%$ & & & \\
\hline
\end{tabular}


In the domestic merger deals (category 2), the CAR accumulated over the event window is $3.06 \%$. During the period of 30 days prior to the merger announcement till the announcement day $(-30$ to 0$)$, the CAR increased by $9.76 \%$ and in the period between the $1^{\text {st }}$ day of announcement till 30 days $(+1$ to +30$)$, it decreased by $12.87 \%$.

In the merger of domestic banks with the foreign banks operating in Pakistan (category 3), the targets earned a significant negative mean CAR $(-10.22 \%)$. For the post event window, the CARs for these targets are negative. On the day of announcement, however, these targets earned an average abnormal return of $1.59 \%$.

\section{Combined banks:}

The mean ARs and CARs for the three combined banks in domestic mergers are given in exhibit7. The mean CAR for the combined banks is positive and substantial. However, the combined CAR has been increased largely due to a very high CAR earned by the merger deal of NIB and PICIC. In the NIB-PICIC merger, the shareholders of both banks have accumulated substantial positive CARs, with a mean CAR of $32.2 \%$. The returns earned by the bidder (PICIC), however, are much higher compared to those earned by the target shareholders. The other two merger deals have reported negative mean CARs showing that the merger deals accumulated losses for the combined entities. For these two merger deals, both bidders and targets reported negative CARs.

Exhibit7: Mean abnormal and cumulative abnormal returns of combined banks in domestic mergers

\begin{tabular}{|l|c|c|c|c|}
\hline & NIB-PICIC & $\begin{array}{c}\text { Combined } \\
\text { FIDELITY }\end{array}$ & KASB-PLATINUM & Group \\
\hline Mean AR & 0.779 & -0.413 & -0.096 & 0.090 \\
\hline Standard Error & 0.237 & 0.474 & 0.277 & 0.2101 \\
\hline t-statistic & $3.288^{*}$ & -0.870 & -0.347 & 0.4295 \\
\hline Mean CAR & 32.188 & -1.820 & -4.316 & 8.684 \\
\hline Standard Error & 1.919 & 1.195 & 0.481 & 0.745 \\
\hline t-statistic & $16.772^{*}$ & -1.523 & $-8.980^{*}$ & $11.657^{*}$ \\
\hline
\end{tabular}

*significant at 5\%

\section{Summary and Concluding Remarks}

The paper investigates the short-term value creation associated with the mergers and acquisitions in the banking sector of Pakistan from 2003 to 2008. The wealth for the shareholders of target and bidder banks is examined by estimating the abnormal returns and cumulative abnormal returns for a 61-day period surrounding the merger announcement. The study finds that the targets and bidders of the bank mergers in Pakistan accumulate significant returns associated with merger deals. For the individual target or bidder bank, these abnormal 
returns range from significant positive to significant negative. For the combined target group, the study documents negative excess returns, where as for the combined bidder group, it reports positive mean cumulative return.

This is the first study of value creation surrounding the merger deals in the context of Pakistan's banking sector. However, the study includes a small sample of seven merger deals and examines the short term wealth effects. Future researches can be conducted on larger set of merger deals. The studies can also be conducted for the merger deals in other sectors of the market. Moreover, medium to long-term effects can also be examined either through the event study methodology or through examining the firms' accounting performance indicators before and after the merger deals.

\section{References}

Anand, M. and J. Singh, 2008. Impact of Merger Announcements on Shareholders' Wealth: Evidence from Indian Private Sector Banks, Vikalpa: Journal for Decision Makers, vol. 33(1): 35-54.

Altunbas, Y. and D.M. Ibanez, 2004. Mergers and Acquisitions and Bank Performance in Europe: The role of Strategic Similarities, European Central Bank Working Paper Series, no.398: October, 1-37.

Andrade, G., M.L. Mitchell and E. Stafford, 2001. New Evidence and Perspectives on Mergers, Journal of Economic Perspectives, vol. 15(2), pp. 103-120.

Asquith, P., 1983. Merger Bids, Uncertainty and Stockholder Returns", Journal of Financial Economics, vol. 11: 51-83.

Ben-Amar, W. and P. Andre,2006. Separation of Ownership from Control and Acquiring Firm Performance: The Case of Family Ownership in Canada, Journal of Business Finance and Accounting, vol. 33,(3-4): 517-543.

Boateng, A., W. Qian and Y. Tianle,2008. Cross-Border M\&As by Chinese Firms: An Analysis of Strategic Motives and Performance, Thunderbird International Business Review, vol. 50(4): 259-270.

Campa, J.M. and I. Hernando, 2004. Shareholder Value Creation in European M\&A, European Financial Management, vol. 10(1): 47-81.

Cybo-Ottone, A. and M. Murgia, 2000. Mergers and Shareholder Wealth in European Banking, Journal of Banking \& Finance, vol. 24(6): 831-859.

Dickerson, A.P., H.D. Gibson and E. Tsakalotos, 1997. The Impact of Acquisitions on Company Performance: Evidence from a Large Panel of UK Firms, Oxford Economic Papers, vol. 49: 344-361.

Fama, E. 1970. Efficient Capital Markets: A Review of Theory and Empirical Work, Journal of Finance, vol. 25(2): 383-417.

Franks, J. and R.S. Harris, 1989. Shareholder Wealth Effects of Corporate Takeovers: the U.K. experience 1955-1985, Journal of Financial Economics, vol. 23(2): 225-249.

Kiymaz, H. and H.K. Baker, 2008. Short-Term Performance, Industry Effects, and Motives: Evidence from Large M\&As, Quarterly Journal of Finance and Accounting, vol.47(2): 1740 . 
Healy, P.M., K.G. Palepu and R. Ruback, 1992. Does Corporate Performance Improve After Mergers?, Journal of Financial Economics, vol. 31(2): 135-175.

Lindblom, T. and C.V. Koch,2002. Cross-Border Bank Mergers and Acquisitions in the EU, The Service Industries Journal, vol.22(4): 41-72.

Meeks, G. 1977.Disappointing Marriage: Gains from Mergers, New York: Cambridge University Press.

Mishra, A. K., and R. Goel, 2005. Returns to Shareholders from Mergers: The Case of RIL and RPL Merger. IIMB Management Review, vol. 17(3): 69-80.

Muslim Commercial Bank Limited. Quid Pro Quo. MCB Bank’s Ecnomic Report on Mergers and Acquisitions, vol. 33.

Ravenscroft, D. and F.M. Scherer, 1987. Life After Takeovers, Journal of Industrial Economics, vol. 36(2): 147-156.

Roberts, V., 1967. Statistical Versus Clinical Prediction of Stock Market. CRSP Working Paper, University of Chicago.

Spyrou, S., and G. Siougle, 2007. Mergers and Acquisitions of Non-Financial Firms in Europe: The Case of the Athens Stock Exchange. Applied Economics Letters, vol.14: 523527.

State Bank of Pakistan 2006. SBP Financial Stability Review.

Tuch, S. and N.O. Sullivan, 2007. The Impact of Acquisitions on Firm Performance: A Review of the Evidence, International Journal of Management Reviews, vol.9(2): 141-170.

APPENDIX 1: ARs and CARs of category-wise target banks

\begin{tabular}{ccccccc}
$\begin{array}{c}\text { Event } \\
\text { Day }\end{array}$ & \multicolumn{2}{c}{ Category $\mathbf{1}$} & \multicolumn{2}{c}{ Category 2} & \multicolumn{2}{c}{ Category 3} \\
& AR & CAR & AR & CAR & AR & CAR \\
30 & -1.218 & 7.009 & 0.872 & -3.058 & 1.065 & -10.214 \\
29 & -0.106 & 8.227 & 1.025 & -3.930 & 1.301 & -11.280 \\
28 & 1.469 & 8.332 & -1.626 & -4.955 & 4.218 & -12.581 \\
27 & -1.877 & 6.863 & -2.060 & -3.330 & 0.963 & -16.799 \\
26 & -0.408 & 8.740 & 1.042 & -1.270 & -1.593 & -17.762 \\
25 & 1.462 & 9.147 & -1.062 & -2.312 & 1.498 & -16.169 \\
24 & -2.465 & 7.686 & -0.931 & -1.250 & -1.000 & -17.667 \\
23 & 0.446 & 10.151 & -2.888 & -0.319 & -1.617 & -16.667 \\
22 & 1.538 & 9.705 & 3.899 & 2.568 & -0.397 & -15.050 \\
21 & -2.363 & 8.167 & -0.618 & -1.331 & -0.166 & -14.653 \\
20 & -0.993 & 10.529 & -3.987 & -0.713 & -2.220 & -14.487 \\
19 & -0.508 & 11.523 & -0.242 & 3.274 & 0.204 & -12.268 \\
18 & -0.049 & 12.031 & 0.923 & 3.516 & -0.945 & -12.472 \\
17 & 1.137 & 12.080 & 0.521 & 2.593 & -1.155 & -11.527 \\
16 & -0.362 & 10.943 & -1.048 & 2.073 & -1.268 & -10.371 \\
15 & -1.932 & 11.305 & -1.499 & 3.121 & -0.780 & -9.104 \\
14 & 0.344 & 13.237 & -0.877 & 4.620 & -0.788 & -8.324 \\
13 & -0.048 & 12.893 & 0.570 & 5.497 & -0.566 & -7.536 \\
12 & -1.279 & 12.941 & -2.459 & 4.926 & -1.587 & -6.970 \\
& & & & & & \\
\hline
\end{tabular}




\begin{tabular}{|c|c|c|c|c|c|c|}
\hline \multicolumn{5}{|c|}{ Business Review - Volume 9 Number 2} & \multicolumn{2}{|c|}{ July - December 2014} \\
\hline 11 & -0.577 & 14.221 & -0.934 & 7.385 & 0.775 & -5.382 \\
\hline 10 & -0.560 & 14.797 & -0.933 & 8.319 & 1.324 & -6.158 \\
\hline 9 & 0.179 & 15.358 & -0.578 & 9.252 & -0.667 & -7.482 \\
\hline 8 & -0.849 & 15.179 & 1.128 & 9.830 & 0.469 & -6.815 \\
\hline 7 & 0.199 & 16.028 & 0.406 & 8.702 & 0.206 & -7.284 \\
\hline 6 & -1.065 & 15.829 & -2.447 & 8.297 & -0.275 & -7.490 \\
\hline 5 & 0.486 & 16.894 & -1.154 & 10.743 & -0.256 & -7.216 \\
\hline 4 & -0.238 & 16.408 & -1.213 & 11.897 & -1.570 & -6.959 \\
\hline 3 & 3.148 & 16.645 & -2.313 & 13.110 & -0.143 & -5.390 \\
\hline 2 & -3.209 & 13.497 & 1.763 & 15.424 & -0.317 & -5.246 \\
\hline 1 & 1.452 & 16.706 & 3.850 & 13.661 & 1.081 & -4.929 \\
\hline 0 & 4.913 & 15.254 & 1.134 & 9.811 & 1.593 & -6.010 \\
\hline-1 & 0.637 & 10.340 & 1.709 & 8.676 & 0.974 & -7.603 \\
\hline-2 & 0.354 & 9.703 & -2.891 & 6.968 & -0.726 & -8.577 \\
\hline-3 & -0.122 & 9.349 & 0.440 & 9.858 & 1.040 & -7.851 \\
\hline-4 & 5.811 & 9.471 & -0.541 & 9.419 & 2.952 & -8.892 \\
\hline-5 & -0.863 & 3.661 & 0.225 & 9.960 & 0.090 & -11.843 \\
\hline-6 & -1.400 & 4.523 & 1.269 & 9.735 & 1.862 & -11.933 \\
\hline-7 & -1.651 & 5.923 & -0.649 & 8.466 & -0.311 & -13.795 \\
\hline-8 & -2.053 & 7.575 & 1.383 & 9.115 & -1.153 & -13.484 \\
\hline-9 & 1.459 & 9.628 & -0.465 & 7.733 & -0.470 & -12.332 \\
\hline-10 & 2.450 & 8.169 & 0.855 & 8.198 & -1.110 & -11.861 \\
\hline-11 & 0.378 & 5.720 & -1.630 & 7.342 & -0.301 & -10.752 \\
\hline-12 & 1.738 & 5.342 & 3.454 & 8.973 & 0.327 & -10.451 \\
\hline-13 & -0.583 & 3.604 & 1.846 & 5.519 & -0.323 & -10.778 \\
\hline-14 & -0.310 & 4.187 & -0.338 & 3.673 & -0.677 & -10.455 \\
\hline-15 & 2.276 & 4.497 & 2.853 & 4.011 & -0.336 & -9.778 \\
\hline-16 & -0.415 & 2.221 & -4.447 & 1.158 & -0.979 & -9.442 \\
\hline-17 & -0.833 & 2.636 & 0.298 & 5.604 & -0.191 & -8.463 \\
\hline-18 & 1.350 & 3.469 & 6.032 & 5.306 & -0.669 & -8.271 \\
\hline-19 & -4.043 & 2.119 & -1.355 & -0.726 & -1.219 & -7.602 \\
\hline-20 & 0.247 & 6.162 & 1.701 & 0.629 & -1.542 & -6.383 \\
\hline-21 & 0.724 & 5.915 & 1.806 & -1.072 & -0.612 & -4.841 \\
\hline-22 & -1.169 & 5.192 & 1.043 & -2.878 & -1.376 & -4.228 \\
\hline-23 & -0.740 & 6.361 & 0.700 & -3.921 & 0.842 & -2.852 \\
\hline-24 & 3.094 & 7.101 & -1.213 & -4.621 & -1.293 & -3.694 \\
\hline-25 & -0.665 & 4.007 & -1.837 & -3.408 & -1.066 & -2.401 \\
\hline-26 & -0.394 & 4.672 & 2.510 & -1.571 & 0.684 & -1.334 \\
\hline-27 & -0.088 & 5.066 & 0.098 & -4.080 & -0.043 & -2.018 \\
\hline-28 & 2.523 & 5.154 & -1.399 & -4.179 & -2.449 & -1.975 \\
\hline-29 & 2.893 & 2.631 & -0.701 & -2.780 & -0.042 & 0.473 \\
\hline-30 & -0.262 & -0.262 & -2.079 & -2.079 & 0.515 & 0.515 \\
\hline Mean & 0.115 & 8.893 & -0.050 & 3.855 & -0.167 & -8.871 \\
\hline
\end{tabular}

